\title{
Questioning techniques used by Foundation Phase Education students teaching mathematical problem-solving
}

\begin{tabular}{|c|c|}
\hline \multicolumn{2}{|c|}{$\begin{array}{l}\text { Authors: } \\
\text { Gina Steyn }{ }^{1} \\
\text { Stanley A. Aden }\end{array}$} \\
\hline \multicolumn{2}{|c|}{$\begin{array}{l}\text { Affiliations: } \\
{ }^{1} \text { Foundation Phase } \\
\text { Department, Faculty of } \\
\text { Education, Cape Peninsula } \\
\text { University of Technology, } \\
\text { Cape Town, South Africa }\end{array}$} \\
\hline \multicolumn{2}{|c|}{$\begin{array}{l}{ }^{2} \text { Intermediate Phase } \\
\text { Department, Faculty of } \\
\text { Education, Cape Peninsula } \\
\text { University of Technology, } \\
\text { Cape Town, South Africa }\end{array}$} \\
\hline \multicolumn{2}{|c|}{$\begin{array}{l}\text { Corresponding author: } \\
\text { Gina Steyn, } \\
\text { steyn.gina@gmail.com }\end{array}$} \\
\hline \multicolumn{2}{|c|}{$\begin{array}{l}\text { Dates: } \\
\text { Received: } 31 \text { July } 2017 \\
\text { Accepted: } 02 \text { Nov. } 2019 \\
\text { Published: } 27 \text { Feb. } 2020\end{array}$} \\
\hline \multicolumn{2}{|c|}{$\begin{array}{l}\text { How to cite this article: } \\
\text { Steyn, G. \& Adendorff, S.A., } \\
2020, \text { 'Questioning } \\
\text { techniques used by } \\
\text { Foundation Phase Education } \\
\text { students teaching } \\
\text { mathematical problem- } \\
\text { solving', South African } \\
\text { Journal of Childhood } \\
\text { Education 10(1), a564. } \\
\text { https://doi.org/10.4102/ } \\
\text { sajce.v10i1.564 }\end{array}$} \\
\hline \multicolumn{2}{|c|}{$\begin{array}{l}\text { Copyright: } \\
\text { (c) 2020. The Authors. } \\
\text { Licensee: AOSIS. This } \\
\text { is licensed under the } \\
\text { Creative Commons } \\
\text { Attribution License. }\end{array}$} \\
\hline \multicolumn{2}{|l|}{ Read online: } \\
\hline 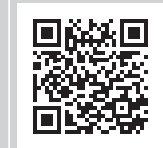 & $\begin{array}{l}\text { Scan this QR } \\
\text { code with your } \\
\text { smart phone or } \\
\text { mobile device } \\
\text { to read online. }\end{array}$ \\
\hline
\end{tabular}

Background: Developing the questioning skills of Foundation Phase Education students when teaching mathematical problem-solving is often a neglected area of student curricula.

Aim: This gap in mathematics programme is the focus of this study. Three main components were identified: presentation of mathematical problem-solving, the role of the Foundation Phase Education student in shared action and the questioning practice of the pre-service teacher.

Setting: This study is embedded in an amalgamated theoretical framework of three theories: relational theory, hermeneutical theory of Davis and the revised taxonomy of Bloom. This qualitative, interpretive study was conducted in a grade 1 class. Seven Foundation Phase pre-service students were purposively selected to participate in the study.

Methods: Triangulation of a multitude of research instruments ensured verification of data. The case study consisted mainly of the observation and analysis of six lessons. The framework of Tesch was used to interpret the data.

Results: An outcome of the case study is a concise description of the use of questioning when teaching mathematical problem solving. Students in the selected sample generally struggled to ask questions and expressed the need for skills training.

Conclusion: The student participants seemed unsure of how to use questioning skills optimally to elicit useful responses from their learners. Recommendations are made for enabling Foundation Phase students to learn the necessary skills to ask questions effectively in the problem solving segment of the curriculum.

Keywords: Foundation Phase; mathematical problem-solving; questioning skills; pre-service teacher education; questioning practice; stimulating questions.

\section{Introduction}

A number of strategies can be implemented to solve mathematics problems. Haylock (2010) considers the use of questions as a key strategy for doing so. Haylock (2010:57) asserts that to 'help children to develop problem solving strategies in mathematics, such as clarifying the givens and the goal, ask them questions...'. Knowing how to set learners' stimulating questions is considered a means to stimulate learners' mathematical knowledge and understanding. Questioning is an integral part of effective teaching and learning (Way 2008:23). Teachers can enhance learners' understanding through the types of questions they ask and their responses to learners' answers (Piccolo et al. 2008:380).

Well considered questions that awake critical thinking and mathematical understanding can enhance investigation, analysis, interpretation, formulation and communication (Ong, Lim \& Ghazali 2010:89). A common principle of effective communication is that when you expect a specific response, you have to ask a specific question to lead the respondent to the expected answer. The technique of posing effective questions is pivotal for effective communication and for exchanging information. Questioning as a didactical technique is viewed by Craig and Cairo (2005) as a process comprising five strategies: planning, presentation, encouragement to participate, processing of responses and reflection about practice.

The research question that guided this research study was the following: which questioning techniques do Foundation Phase Education students use when teaching mathematical problem-solving lessons? 
Formulation of the problem statement was based on the first author's personal experience as a tertiary lecturer in Foundation Phase mathematics. The needs analysis revealed the following: Foundation Phase Education students are aware of the important role of effective questioning practice when teaching mathematical problem-solving, but showed limited skills when applying such strategies during lesson presentations.

\section{Theoretical framework}

This study built on an amalgamation of the relational theory of Richard Skemp (1979:44), the hermeneutical theory of Brent Davis (1996: ix) and the revised taxonomy of Bloom (Orey 2010:43).

Problem-solving is the focus of mathematics (DoE 2009:57). To solve mathematical problems, mathematical understanding needs to be developed (DoE 2009:57). Richard Skemp's relational theory provides a lens for studying the child's ability to make sense of mathematical problem-solving. Relational understanding, where new knowledge is created from old knowledge, is the main principle of this theory (Skemp 1979:44). Application of relational understanding leads to understanding and the ability to make connections between related ideas and topics (Brown 1995:n.p.). According to Skemp (1971:25), primary and secondary concepts are formed during the learning process. Primary concepts are formed through physical engagement in the learning process. The learner can be guided to secondary concepts through purposeful questioning. Secondary concepts are formed through the abstracting of primary concepts. Skemp (1971:31) states that the root cause of learner difficulty in solving mathematical problems is the inability to comprehend primary mathematical concepts. Skemp's theory promotes relational understanding to create better understanding.

Language is considered the main instrument in the process of creating relational understanding between old and new knowledge (Brown 1995:n.p.). The important role of language in this process of creating better understanding leads to the amalgamation of Skemp's theory with that of Davis (1996:ix). The hermeneutical theory of Brent Davis provides a lens for understanding that develops through shared action between the teacher and learner. According to Davis (1996), environment and understanding are integrated. A child must be led to higher-order thinking through questioning. McDermott and Rakgokong (2013:22) posit that questions are used to focus learners' attention on their own thinking, as well as to direct the process of building connections between old and new knowledge. The key principle of this theory is that understanding cannot be created in isolation, but by means of shared action. The role of the teacher is to create opportunities for shared action while presenting mathematical problem-solving. Askew (2012:19) supports the hermeneutical theory (Davis 1996) when he states that mathematics must be seen as 'preformed' instead of 'performed'. Davis's hermeneutical theory (1996:358) moves mathematics to the auditive discipline of teaching, where language and shared action are the focus.
Shared action when teaching mathematical problem-solving must be led by effective questioning (McDermott \& Rakgokong 2013:22). The revised taxonomy of Bloom (Orey 2010:43) makes it possible to present questions in a hierarchy of the following thinking levels: remembering (lowest level), understanding, applying, analysing, evaluating and creating (highest level). Progressive thinking is stimulated by presenting questions on the hierarchy of thinking levels (Orey 2010:43). According to Bloom's taxonomy (Mardigan 2011), understanding and intellectual abilities develop when the learner is led through a hierarchy of thinking levels. Taxonomies and frameworks serve as tools for teachers as they plan for and formulate quality questions (Walsh \& Sattes 2012).

Upon unpacking the research topic to clarify the main parts of the investigation, three main components were identified: presentation of mathematical problem-solving, the actual role of the Foundation Phase Education student and questioning techniques applied by the pre-service teacher.

Each component of the research topic was viewed in terms of one part of the amalgamated theoretical framework. The presentation of mathematical problem-solving was viewed through the lens of Skemp's (1979:44) relational theory. Davis's (1996:ix) hermeneutical theory was used as a theoretical lens for observing the role of the Foundation Phase Education student when creating shared action and Bloom's revised taxonomy (Orey 2010:43) was used as the theoretical lens for the questioning techniques of the pre-service teacher.

\section{Literature review}

The practice of effective questioning promotes learning and understanding, as the aim is to focus the attention of learners on specific aspects of the learning situation (Craig \& Cairo 2005). Ewing and Whittington (2007) stated that all learning begins with posing questions. The frequency of questions must not be the only focus, but rather the participation and developing of understanding in the learner (Holster 2006). Effective questioning compels learners to participate and to share their thinking (Holster 2006).

Questioning practice must enable the child to make connections between old and new knowledge (Teodoro et al. 2011:21). From a hermeneutical viewpoint, connections are made through shared action (Davis \& Sumara 1997:117). Enactivism as a model places a responsibility on the teacher to adopt the interpretive paradigm when presenting mathematical problem-solving and using questioning to facilitate the shared action.

Purposeful questioning is the formulation of specific questions to focus on a specific aspect of the learning situation (Odendal \& Gouws 2005:289). Whisler (2012) states that purposeful questioning must obtain the following qualities: focuses on the important aspect of the learning situation and promotes higher-order thinking, thereby deepening understanding.

Piccolo et al. (2008:380) state that open questions are more appropriate to use to stimulate intellectual thinking, 
problem-solving and understanding. Fox and Surtees (2010:26) note that the use of open questions is the start to the investigation of knowledge. A more interactive lecturing style is promoted through the use of open questions and shared action takes place in classroom discussions.

It is important for teachers to accommodate learners' answers in effective ways. This means that answers could be accepted as correct, or a range of follow-up questions could be posed. When an incorrect answer is given, neutral comments must be made. Incorrect answers must be followed up by means of rephrasing the original question and presenting it in an alternative way (Piccolo et al. 2008:380).

When a mathematical problem is posed, knowledge or skill gaps may exist that prevent the learner from providing the solution immediately or reasonably quickly. According to Fox and Surtees (2010:47), a gap exists between the knowledge that the learner possesses and the new knowledge that needs to be created to find the solution to the problem. Therefore, questions must be posed in a way that directs the child's attention (Haylock 2010:57). The bridging of the gap is viewed through the theoretical lens of Davis (1996:105), who states that cognition and environment are integrated through shared action. Rigelman (2007:313) proposes a cyclic model which consists of the following steps: investigation, developing of methods, as well as the provision and discussion of solutions. Questions are a binding factor between all of these steps. 'Teachers use questions to control classroom interactions, including stimulating the level of thinking which occurs' (Ewing \& Whittington 2007:91).

Mathematical problem-solving implies the presence of a real problem that must be solved (Van den Heuvel-Panhuizen, Kuhne \& Lombard 2012:204), and also that the learner has to make choices, interpret, formulate, model, investigate solutions and communicate (Askew 2012:19). Problem-solving ultimately involves the process of overcoming an unknown situation when no direct solution is seemingly present (Naude \& Meier 2014:104). The learner must reflect on his or her understanding and how he or she is to solve the problem. Understanding the mathematics would allow the learner to build important mathematical concepts during this process (Askew 2012:20). The child develops a sense of 'what' and 'how' of mathematics by means of mathematical problem-solving.

Children must be led to the notion that mathematics makes sense (Van de Walle \& Lovin 2007:30). The teacher must create an atmosphere of inquiry, trust and engagement (Van de Walle \& Lovin 2007:14). Problems are posed and learners struggle towards a solution. Shared action must take place to assist the learner in reaching a solution, as seen through the theoretical lens of Davis's hermeneutical theory (1996:ix). According to Walsh and Sattes (2012):

I suggest that there are only two good reasons to ask questions in class: to cause thinking and to provide information to the teacher about what to do next. (p. xx)
Mathematical problem-solving clearly provides the opportunity to get a glimpse of the learner's level of understanding, a window to the child's thinking, and serves as an assessment instrument to measure the child's level of understanding and relational thinking abilities (Charlesworth \& Leali 2012:373). Walsh and Sattes (2012) strengthen this argument by stating that the thinking process and assessment are facilitated by questions.

\section{Research methodology}

This case study was conducted within a qualitative interpretive paradigm. The qualitative data were gathered, analysed and interpreted. As qualitative researcher, the first author entered the research field as a non-participant observer to describe the questioning practice of Foundation Phase Education students, to analyse findings and to interpret them. The following four steps were applied in the data collection process (Terre Blanche, Durrheim \& Painter 2012:311-314): preparation for the process, identifying the sample, written consent to conduct the research study and field observation.

The research plan was revised continuously and adjustments were made where necessary as social research does not always follow a fixed plan (Creswell 2009:141). According to Thomas (2011:14), the researcher needs to plan for change while doing social research. The case study took approximately two and a half months to complete. Planning and preparation for the case study occurred as follows:

- attaining informed consent from the university, Western Cape Education Department and schools to conduct the research

- announcement to possible candidates of opportunity to participate in the research project

- identification of participants and purposive selection of seven Foundation Phase pre-service students to participate

- continual communication with schools and class teachers

- continual communication with students who presented lessons

- attaining informed consent from parents for their Grade 1 children to participate in the research study

- lesson discussion with students presenting lessons

- conducting interview with focus group

- administering individual questionnaires.

The first step was to ensure ethical clearance. Informed consent was obtained from all the participants and relevant institutions. Anonymity, voluntarily participation and ethical considerations were fully attended to during the study.

The case study consisted of six lessons presented by BEd Foundation Phase Education students in their fourth year of study. The selection criteria used for students to participate in the study were as follows: each student had to be registered for BEd, be in Foundation Phase Fourth Year in 2014 and must have obtained a minimum $75 \%$ in mathematics lesson presented during his or her third year in 2013. The opportunity to participate was proposed to all the BEd 4 Foundation Phase students and the study criteria were communicated. 
Students had to indicate their willingness to participate and one student was randomly selected for the pilot study. Six other students were purposively selected to present the six lessons of the case study in alphabetical order.

A pilot study was conducted at a grade 1 class in a nearby school, with a similar environment and social status as the class used for the case study. Observation instruments were tested and found to be adequate.

The same class and the same group of children were used for each lesson. A group of 12 children with varying intellectual abilities was selected randomly by the class teacher. The focus of each lesson was mathematical problem-solving. The lesson was presented at the back of the class, while the other children were busy with tasks at their desks. The reason for this arrangement was to create a normal class setting within which differentiated teaching could occur. The duration of each lesson was approximately half an hour. Lesson content as received from the class teacher was discussed, but the student teacher planned the lesson as well as the presentation thereof independently.

Triangulation of multiple research instruments ensured rigour and verification of data. Research instruments consisted of digital video disk (DVD) recordings, transcription of lessons, observation schedules, an unstructured interview with the focus group and individual questionnaires for the presenters. The focus group consisted of the six student teachers who presented lessons during the case study, as well as the student teachers responsible for the lesson of the preliminary study.

All the teaching moments, perceptions, data and interpretations of the participants were recorded to provide a holistic account of the case study. Research roles of participants were driven by the aim to answer the research question, namely which questioning techniques Foundation Phase students used when teaching mathematical problem-solving.

According to Maree (2011:85), the observer should look for patterns in the behaviour of a specific community to understand the phenomenon. An effort was made in order for the researchers to stay unbiased and uninvolved, without affecting the dynamic of the phenomenon in its natural setting by not participating in any way.

The six lessons were followed by an unstructured interview with the focus group to capture the perceptions of participants (Oliver 2010:106). An in-depth interview was conducted and the aim was primarily to use the information to generate and formulate new questions for follow-up interviews. Participants shared their experiences, perceptions and opinions concerning the use of questioning techniques when presenting mathematical problem-solving. Data collected showed that the participants had limited knowledge concerning the optimal use of questioning as a teaching tool.

The focus group interview was followed by individual questionnaires involving all the participants. The questionnaire consisted of reflection questions. At that particular point of data collection, saturation was reached. According to Terre Blanche et al. (2012:228), saturation is the point where no new data are collected and no new codes emerge from the data.

Five steps were used in the process of interpretive analysis:

- knowing the data

- recording codes that emerged naturally from the data in an inductive way

- organising the data by breaking them up into relevant parts

- forming themes by creating categories from the codes

- interpreting and writing the written report.

The framework of Tesch (1991) was used to interpret the data. His framework follows a systematic process.

Data analysis and collection took place simultaneously. The researchers made informal notes during the process of data collection and data were coded and segmented. Although data were segmented and categorised, it was a flexible and personal process which the researchers had to individualise (Tesch 1991).

The following categories emerged from the coding of data: questioning on different thinking levels; accommodation of learners' responses; purposeful questioning; the child's development; classroom atmosphere; presenters answering their own questions; the use of different types of questions; follow-up on questions; reflection and discussion; repetition; child-centred approach; didactical skills of the presenter; listening and learners' attention span; visual aids; assisting the child with difficulties; passive/active learners; engaging learners in the learning process; theoretical knowledge; motivation of learners; structure of questions; mathematical problem-solving; formulation of questions; planning of questions; experience of presenter; waiting time after a question is posed; language development; cognitive development and discipline.

The data analysis was divided into two cycles. Cycle 1 consisted of coding and categorising as mentioned above. Cycle 2 consisted of identifying patterns and themes that emerged from cycle 1's themes and categories. The research process was constantly measured against the following questions:

- Are the theoretical framework and methodology of the research project clear?

- Is the context of the study stated clearly?

- Is the sample planned and recorded?

- Are the processes of data analysis planned and verified?

- Is the triangulation of data done to ensure validity?

The following six categories emerged from the hermeneutical, circular process of analysis (sub-categories are shown in brackets):

- questioning techniques that lead to understanding (mathematical problem-solving, repetition, different types of questions, structure of questions, purposeful questioning and the formulating of questions) 
- effective questioning practice (theoretical knowledge about questioning practice, experience, planning of questions, competencies of the presenter and the presenter that answers his or her own questions)

- child as departure point for the use of questioning (visual aids, participation of the child in the learning process, child-centred approach, listen and attention, cognitive development and language abilities)

- shared action (waiting time, reflection and discussion, accommodation of pupils' responses and the follow-up of questions)

- classroom atmosphere (atmosphere of the classroom, passive/active participants, planning of questions, skills of the presenter and presenter answering his or her own questions)

- differentiation and inclusive education (questioning on different thinking levels, child's development, assisting the child that has difficulties with mathematical problem-solving).

\section{Findings}

Six themes emerged during cycle 2 of the data analysis and are discussed by presenting data and empirical evidence.

\section{Theme 1: Questioning that leads to understanding}

By using questioning as an instrument, the child in this investigation was led along the continuum of understanding from old to new knowledge. The focus of the data analysis was to determine to which extent this took place during the lesson presentations. The frequency of questioning and how it was used to lead the child along the continuum of understanding to new knowledge was investigated.

Questioning was occasionally used in the course of the lessons, yet not as frequently as expected. When questioning was used, the focus was to lead the learner to the correct answer or solution and not necessarily to guide the learner to the level of understanding and higher-order thinking. The following closed questions (with learner responses) were commonly used by presenters and are evidently on a basic level:

Student Teacher 1: 'How many dots did we have then?' (female, fourth year student)

Learner: ' 6 ' (Grade 1, 7 years old)

Student Teacher 2: 'And how many apples were on each tree?' (female, fourth year student)

Learner: '2' (Grade 1, 7 years old)

Student Teacher 3: 'And how many bees on each flower?' (female, fourth year student)

Learner: '3' (Grade 1, 7 years old)

The focus group and questionnaires revealed that the common expectation of the presenters was to lead the learner to the correct answer as the ultimate aim of questioning. The data show that the presenters of the lessons were dissatisfied with the number of questions they posed as well as in their abilities to formulate questions that stimulate learners to respond readily. They expressed the need to broaden their questioning techniques with respect to the frequency and quality of questions on different thinking levels:

Student Teacher 1: 'Learners require much more guidance by means of questioning.' (female, fourth year student)

Student Teacher 2: '... There were only three main questions that I could ask ...' these did not allow enough guidance to be given to learners.' (female, fourth year student)

Although the presenters tried to lead the learners to better understanding by means of questioning, they did not succeed in their goal. They merely used the same type of questions repeatedly and used closed questions frequently:

Student Teacher 1: 'I have asked many questions, every time, over and over to compel learners to think and come up with solutions themselves.' (female, fourth year student)

However, some students indicated that repetition of questions added quality to the process, as indicated in the following excerpt:

Student Teacher 2: 'It feels as if I repeated many times, but I feel it's a good thing.' (female, fourth year student)

Student Teacher 3: 'I also think that with the little ones you have to repeat ...' (female, fourth year student)

Mainly closed questions were used, and only a few openended questions were encountered.

The presenters used repetition of questions in an attempt to clarify concepts and mathematical problems for the learners. Instead of rephrasing questions, questions were frequently repeated.

\section{Theme 2: Effective questioning practice}

Using questioning as a teaching strategy to stimulate and direct learners' thinking was a hurdle that students found hard to clear:

Student Teacher 4: '.. If only my planning had been better, and if only I considered all possible solutions?' (female, fourth year student)

Several external factors might have inhibited the quality of questioning, such as discipline and general classroom structure. Communication and classroom management skills of the presenters played a cardinal role in the use of effective questioning:

Student Teacher 5: 'It's difficult to remain organised the whole time ... you think about going to the writing board with them, and sit doing the sum.' (female, fourth year student)

Student Teacher 6: '... Guide the learners just to a certain point and we don't have enough knowledge to give further guidance.' (female, fourth year student)

Few of the presenters seemed to be adequately skilled in using questions optimally. The presenters needed to take control of the learning situation to ensure success. 
Participants made an effort to encourage learners to participate actively in answering particular questions, but these attempts were mostly unsuccessful as emphasised:

Student Teacher 6: 'I only posed a few questions and the questions did not provide much guidance to learners. I don't know what to ask ...' (female, fourth year student)

The students suggested that they should be allowed more time to practise questioning skills and needed more specialised training in this specific style of using questions:

Student Teacher 5: 'I feel more time can be spent on questioning [in our course]. How to gauge your learners and how to adapt or adjust the types of questions you want to ask.' (female, fourth year student)

Student Teacher 6: 'Good questioning techniques during [the teaching of] problem-solving is like a teaching-aid on its own, and thus requires much work and practice, and also guidance.' (female, fourth year student)

Accommodation of learners' responses was not always handled in the most appropriate manner if the following is considered:

Student Teacher: 'How many dots did we have then?'

(female, fourth year student)

Learner: '6' (Grade 1, 7 years old)

Student Teacher: 'Good. We had 3 and then we d ...?'

(female, fourth year student)

Learner: 'doubled' (Grade 1, 7 years old)

Student Teacher: 'Now we have ...?' (female, fourth year student)

Learner: '6' (Grade 1, 7 years old)

The student teacher in this case merely looked for particular answers, prompting the learner to give the particular answer or response. When a learner gave the correct answer, the presenter seemed satisfied and moved on to the next mathematical problem. The ideal practice would be to use the answer to pose more open-ended questions on higher thinking levels to promote better understanding and to verify how the solution was arrived at. When an incorrect answer was given, presenters generally did not use questioning techniques to guide the learner to the correct answer. The participant in most cases simply stated the correct answer, instead of rephrasing the question in a way that would compel the learner to respond appropriately.

\section{Theme 3: Shared action}

Theme 3 focuses on the role of Foundation Phase students in the hermeneutics of mathematical problem-solving during teaching. The importance of waiting time allowed by the teacher after having posed each question is emphasised. Essentially, enough time must be allowed - including response time - for questioning as a way of assisting learners to clarify their thoughts.

Data revealed that participating students showed an awareness of the appropriate use of questions, that is, to lead the child along the continuum of understanding from old knowledge to new knowledge by using questions on different cognitive levels. But that knowledge did not manifest during the lessons. Data revealed the use of closed questions on the two lowest levels of Bloom's revised taxonomy of questioning. This is evident from the following exchange between a student and a learner:

Student Teacher 1: 'How many friends will there be?' (female,

fourth year student)

Learner: '4' (Grade 1, 7 years old)

Student Teacher 1: 'How many do you say?' (female, fourth year student)

Learner: '4' (Grade 1, 7 years old)

Student Teacher 1: 'What happened? Tell me the story. How many did you have?' (female, fourth year student)

Learner: '2' (Grade 1, 7 years old)

Questions were generally not followed up with rephrased or adapted questions or progressive questions.

Little reflection and discussion took place during the lessons and waiting time after a question or answer was as a rule not allowed. Learners' responses were not adequately accommodated, and mostly ignored.

The most important questioning skills are the abilities to formulate clear questions, rephrase questions, lead learners to shared action, use a variety of questioning skills, give responses to learners' answers and distribute questions evenly amongst learners. These questioning skills were only rarely visible during the case study.

\section{Theme 4: The child as a point of departure}

Based on the question-response patterns that emerged during lesson observation and empirical evidence gathering, the conclusion could be reached that the child's age, cognitive developmental stage, language skills and personal needs must be used as a framework for planning the lesson and questions. Students seemed to find it difficult to accommodate those factors in their lesson presentations based on the following:

Student Teacher 1: 'One has to learn to think in different ways.' (female, fourth year student)

Student Teacher 2: 'One needs to think like a child in order to be able to pose the follow-up question ...' (female, fourth year student)

Student Teacher 3: 'How does one ensure that they continue to pay attention? ...' (female, fourth year student)

\section{Theme 5: Classroom atmosphere}

Participating students showed concern about learners' experiences in the mathematics classroom. Their comments corroborated the importance of a congenial classroom atmosphere:

Student Teacher 1: 'The learners were at ease and they had the idea that we were playing a game, and consequently they seemed to grasp what I said quicker.' (female, fourth year student) 
Student Teacher 2: 'The classroom atmosphere was relaxed and the learners were excited.' (female, fourth year student)

Student Teacher 3: 'Participating makes them more interested in what we are busy with.' (female, fourth year student)

\section{Theme 6: Differentiation and inclusive education}

Emerging from themes 1-5, a spontaneous need was frequently expressed by the students to receive further training in the use of questioning to accommodate differentiation and inclusive education:

Student Teacher 1: 'How do you manage the little child who knows much less than the much stronger child?' (female, fourth year student)

Student Teacher 2: 'It's very important that questions are well thought through and structured on different levels in order to accommodate the learners.' (female, fourth year student)

\section{Reflection on findings}

Reflecting on the findings is done in terms of the six themes that emerged during cycle 2 of the data analysis. The discussion integrates findings with the relevant theories and the literature consulted.

\section{Theme 1: Questioning that leads to understanding}

The data related to this theme were viewed through the lens of Skemp's (1971:25) relational theory and questioning occurred on the hierarchy levels of Bloom's revised taxonomy (Orey 2010:43). Limbach and Waugh (2010) promote the use of questioning to determine the learner's level of thinking and understanding. Adedoyin (2010:314) advises that a teacher must be able to use quality questions to facilitate effective learning and reinforces the idea of shared action between teacher and learner when using questions.

It was found that students tended to lead learners towards a predetermined response. This methodology was successful at the very basic level of counting, for example, 'how many bees there are?'. But according to Skemp's (1971:25) relational theory, classification of primary and secondary concepts, leading learners in this way, forecloses on their ability to develop a wide-ranging, authentic and imaginative engagement with problem-solving.

\section{Theme 2: Effective questioning practice}

Because questioning is regarded as an integral part of effective teaching, the art of applying effective use of questioning must be aspired to (Limbach \& Waugh 2010). Questioning during the presentation of mathematics lessons in this case study was viewed through the lens of Bloom's revised taxonomy (Orey 2010:43) and Davis's hermeneutical theory (1996:ix).

Walsh and Sattes (2005), Way (2008) and Whisler (2012) underscore the importance of implementing various techniques to hold the child's attention and facilitate the learning process by posing appropriate questions. Students found it challenging to control large classes while asking pertinent and stimulating questions.

This difficult pedagogic situation drew attention to the nature of the questions asked. Students were largely unable to formulate questions that captured the interest and attention of the learners. This predicament related closely to Davis's (1996) call for an active engagement between the instructor and learner.

\section{Theme 3: Shared action}

This theme is viewed through the theoretical lens of Davis (1996:ix). The questions posed pertaining to this theme do not necessarily promote higher-order thinking (Limbach \& Waugh 2010; Mardigan 2011). From the following example, it is clear that the last part of the question fails to develop the initially promising two sections. Asking how many did you have?' returns the learner to the primary level of recalling information. Answers by learners must be followed up with more challenging questions to promote and direct thinking on higher cognitive levels (Walsh \& Sattes 2005). This distinction reinforces Mardigan's (2011) concern with problem-solving, which is a practice and mental habit that must be developed early on in a learner's career.

Student Teacher 1: 'What happened? Tell me the story. How many did you have?' (female, fourth year student)

\section{Theme 4: The child as a point of departure}

Seen through the amalgamated theoretical lenses of Skemp, Davis and Bloom, the child must be considered as a point of departure when questioning strategies are implemented.

Responses from students showed their awareness of the need to respect the wide range and variety of individual learners' developmental stages. However, although students were aware of this need to identify and work out from each learner's particular cognitive stage, they found it difficult to maintain discipline in the class while at the same time attending to the child as a point of departure. Orey's (2010) hierarchy of thinking skills could not therefore be implemented successfully.

\section{Theme 5: Classroom atmosphere}

The environment of the child plays a significant role in the learning process because the cognitive processes and environmental factors are integrated with each other (Davis 1996:ix). Linder, Powers-Costello and Stegelin (2011) confirm that mathematics must be presented in a humane and child-friendly way to young children. 'High quality teaching in mathematics is about the joy, not imposition and pressure' (Linder et al. 2011:29). Higher-order thinking and understanding are enhanced by creating a classroom in which learners feel safe (Limbach \& Waugh 2010). In this area alone, it was observed that students were cognisant of the importance of an environment conducive to learning and were able to create it reasonably successful. It was noted, 
however, that even in this relaxed situation and in their home language, learners still tended to reply in one-word answers. One-word responses could suggest previous teacher-centred conditioning which did not encourage spontaneous learner responses. This speaks about Davis's (1996) concern with the hermeneutics of mathematical tuition.

\section{Theme 6: Differentiation and inclusive education}

Accommodating learners on different thinking levels addresses such educational needs. Linder et al. (2011) agree with Teodoro et al. (2011) that mathematics for young learners should include helping them to make meaningful connections through play, discovery and exploration in natural environments. Holster (2006) agrees by stating that teaching is a shared action that promotes understanding through help and assistance. Participating students' questions reflect their anxieties and concerns in this regard.

This was the area of greatest weakness evident in the findings. Almost all students acknowledged quite openly that they needed training in this regard. This need summarised the dearth of training in the use of questioning as a key means of teaching mathematics.

\section{Conclusion}

Foundation Phase Education pre-service students seemed unsure of how to use questioning skills optimally, in ways that could elicit useful responses from learners. Student teachers in this study needed more specific education training for developing effective questioning strategies. Although national and international studies highlight the importance of effective questioning practice to lead learners along the continuum of understanding to higher-order thinking, the skills to develop education of this quality are not necessarily conveyed to education students. Bloom's revised taxonomy (Orey 2010:43) may be applied in the process of supporting learners to develop solutions for mathematical problems through questioning.

The six themes that emerged from the data analysis are supportive of the findings. The findings are transferable to relevant mathematics lessons. An important need that was identified was that effective questioning practice for teaching mathematical problem-solving must be explicitly taught to Foundation Phase Education students as part of the curriculum. To promote quality education, effective questioning practice must be used. A framework needs to be developed and implemented as a training programme to promote effective use of questioning by Foundation Phase Education students.

\section{Acknowledgements}

The authors express their gratitude to the Cape Peninsula University of Technology and specifically the Faculty of Education for allowing the use of time and space to perform this research. The authors appreciate the willingness of the participating pre-service students for having availed themselves to become part of the research.

\section{Competing interests}

The authors have declared that no competing interests exist.

\section{Authors' contributions}

All authors contributed equally to this work.

\section{Ethical considerations}

This article followed all ethical standards for a research without direct contact with human or animal subjects.

\section{Funding information}

This research received no specific grant from any funding agency in the public, commercial or not-for-profit sectors.

\section{Data availability statement}

Data are available upon request from the author.

\section{Disclaimer}

The views and opinions expressed in this article are those of the authors and do not necessarily reflect the official policy or position of any affiliated agency of the authors.

\section{References}

Adedoyin, O., 2010, 'An investigation of the effect of teachers' classroom questions on the achievements of students in mathematics: Case study of Botswana Community Junior Secondary School', European Journal of Educational Studies 2(3), 313-328.

Askew, M., 2012, 'Professor's page: Is understanding a proficiency?', Australian Primary Mathematics Classroom 19(1), 19-20, viewed 10 June 2013, from https:// www.questia.com

Brown, M., 1995, 'Obituaries: Professor Richard Skemp', The Independent, viewed 26 March 2013, from https://www.independent.co.uk.

Charlesworth, R. \& Leali, S.A., 2012, 'Using problem solving to assess young children's mathematics knowledge', Early Childhood Education Journal 39(6), 373-382. https://doi.org/10.1007/s10643-011-0480-y

Craig, J. \& Cairo, L., 2005, Assessing the relationship between questioning and understanding to improve learning and thinking (QUILT) and student achievement in mathematics: A pilot study, Appalachia Educational Laboratory at Edvantia, Inc., Charleston, WV, viewed 10 June 2013, from https://www.edvantia.org.

Creswell, J.W., 2009, Research design: Qualitative, quantitative and mixed methods approaches, 3rd edn., Sage, London.

Davis, B., 1996, Teaching mathematics towards a sound alternative, Garland, New York.

Davis, B. \& Sumara, D., 1997, 'Cognition, complexity and teacher education', Harvard Educational Review 67(1), 105-125. https://doi.org/10.17763/ haer.67.1.160w00j113t78042

Ewing, J.C. \& Whittington, M.S., 2007, 'Types and cognitive levels of questions asked by professors during College of Agriculture class sessions', Journal of Agricultura Education 48(3), 91. https://doi.org/10.5032/jae.2007.03091

Fox, S. \& Surtees, L., 2010, Mathematics across the curriculum, Continuum International Publishing Group, London.

Haylock, D., 2010, Mathematics explained for primary teachers, 4th edn., Sage, London.

Holster, T., 2006, Purposeful questioning in mathematics: A guiding framework, ACE Papers, 17, pp. 1-13, viewed 10 June 2013, from https://www.education. auckland.ac.nz.

Limbach, B. \& Waugh, W., 2010, 'Developing higher level thinking', Journal of Instructional Pedagogies 3, 1-9, viewed 03 July 2014, from https://www.aabri.com.

Linder, S.M., Powers-Costello, B. \& Stegelin, D.A., 2011, 'Mathematics in the early childhood: Research-based rationale and practical strategies', Early Childhood Education Journal 39(1), 29-37. https://doi.org/10.1007/s10643-010-0437-6

Mardigan, S., 2011, Guiding learners to using higher-order thinking skills, Greek Orthodox Archdiocese of America Department of Religious Education, Brooklyn, MA.

Maree, K. (ed.), 2011, First steps in research, Van Schaik Publishers, Pretoria.

McDermott, L. \& Rakgokong, L., 2013, EXCELL in teaching mathematics, 9th edn. Creda Communications, Cape Town.

Naude, M. \& Meier, C., 2014, Teaching foundation phase mathematics: A guide for South African students and teachers, Van Schaik Publishers, Pretoria. 
Odendal, F.F. \& Gouws, R.H., 2005, HAT Verklarende Handwoordeboek van die Afrikaanse Taal, 5 de uitgawe, Pearson Education, Kaapstad.

Oliver, P., 2010, Understanding the research process, Sage, London.

Ong, E.G., Lim, C.S. \& Ghazali, M., 2010, 'Examing the changes in novice and experienced mathematics teachers' questioning techniques through the lesson study process', Journal of Science and Mathematics Education in South East Asia 33(1), 86-109.

Orey, M., 2010, Emerging perspectives on learning, teaching and technology, E-Book, London, viewed 22 March 2013, from https://www.etzacorp.co.za.

Piccolo, D.L., Harbaugh, A.P., Carter, T.A., Capraro, M.M. \& Capraro, R.M., 2008 'Quality of instruction: Examining discourse in middle school mathematics instruction', Journal for Advanced Academics 19(3), 376-410. https://doi. org/10.4219/jaa-2008-809

Questioning Techniques, n.d., Mind tools: Essential skills for an excellent career viewed 02 April 2013, from https://www.mindtools.com.

Rigelman, N.R., 2007, 'Fostering mathematical thinking and problem solving: The teacher's role', Teaching Children Mathematics 13(6), 308-314, viewed 12 September 2013, from https://www.nctm.org.

Skemp, R., 1971, The psychology of learning mathematics, Penquin Books, Harmondsworth, Middlesex.

Skemp, R., 1979, 'Goals of learning and qualities of understanding', Mathematics Teaching 88, 44-49.

South Africa, Department of Basic Education (DoE), 2009, Numeracy handbook for foundation phase teachers: Grades R3, Government Printer, Cape Town.
Teodoro, S.D., Donders, S., Kemp-Davidson, J., Robertson, P. \& Schuyler, L., 2011, 'Asking good questions: Promoting greater understanding of mathematics through purposeful teacher and student questioning', Canadian Journal of Action through purposeful teach
Research 12(2), 18-29.

Terre Blanche, M., Durrheim, K. \& Painter, D. (eds.), 2012, Research in practice, 2nd edn., University of Cape Town Press, Cape Town.

Tesch, R., 1991, The nature of qualitative research, viewed 21 May 2013, from https:// www.blackwellpublishing.com.

Thomas, G., 2011, How to do your research project, Sage, London.

Van de Walle, J.A. \& Lovin, L.H., 2007, Elementary and middle school mathematics: Teaching developmentally, 6th edn., Pearson Education, Boston, MA.

Van den Heuvel-Panhuizen, M., Kuhne, C. \& Lombard, A., 2012, The learning pathway for number in the early primary grades, Macmillan, Gauteng.

Walsh, J.A. \& Sattes, B.D., 2005, Quality questioning: Research-based practice to engage every learner, Corwin, Thousand Oaks, CA, viewed 07 July 2014, from http://www.sagepub.com.

Walsh, J.A. \& Sattes, B.D., 2012, Thinking through quality questioning, viewed 07 July 2014, from https://www.brainchildblog.com.

Way, J., 2008, 'Using questioning to stimulate mathematical thinking', Australian Primary Mathematics Classroom 13(3), 22-27, viewed 10 June 2013, from https:// www.aamt.edu.au

Whisler, S., 2012, Cues, questions and advance organizers, viewed 06 July 2014, from https://www.esu4instructionalstrategies.wikispaces.com. 